\title{
Strategic decision making and influence of economic freedoms on foreign direct investment (FDI) in Bosnia and Herzegovina
}

\section{Dragan Milovanović}

University of Banja Luka, Faculty of Economics, Banja Luka, Bosnia and Herzegovina https://orcid.org/0000-0002-5320-7350

\section{Nenad Marković}

University of East Sarajevo, Faculty of Medicine, Foca, Bosnia and Herzegovina

https://orcid.org/0000-0002-5179-5048

\begin{abstract}
Decision making on foreign direct investment (FDI) is a strategic decision for the country, the company, but also the individual, which is strategic. Where to invest, how and when, certainly depends on economic conditions and economic freedoms. Foreign direct investments represent a value of 357 million euros in 2019 , representing a significant factor in the overall development of Bosnia and Herzegovina $(\mathrm{BiH})$. Expectations of an increase in the level of foreign investment are also based on the level of economic freedoms. The research results show a significant impact and positive correlation of economic freedoms on strategic decisions on foreign direct investment in Bosnia and Herzegovina. The role and importance of the impact of economic freedoms on strategic decisions on foreign direct investment became especially important in the conditions of the COVID 19 coronavirus pandemic, when strategic decisions were coupled with even greater risks and sensitivity. The COVID-19 pandemic affected foreign direct investment in the world and expectations regarding the trend of foreign direct investment in $\mathrm{BiH}$. According to preliminary data from the Central Bank of $\mathrm{BiH}$ for the first half of $2020, \mathrm{FDI}$ is lower by $46.7 \%$ compared to the same period in 2019 . Foreign direct investment in less developed countries such as $\mathrm{BiH}$ will be under additional pressure in 2020/2021, due to the impact of the COVID 19 pandemic. The decline in global foreign direct investment in 2020 and 2021 is estimated at $30-40 \%$ as a result of the pandemic. The results of the research cover the period from 1998 to 2020 , and show the existence of a positive correlation between these variables. The analysis used an econometric model of multiple correlation analysis Pearson Correlation.
\end{abstract}

Keywords

strategic decision making, foreign direct investment (FDI), economic freedoms, Bosnia and Herzegovina development

\section{Introduction}

The globalization of the world economy has resulted in the growing importance of foreign direct investment, given the fact that modern economic development is based not only on domestic investment, but also on the mobilization of various sources of foreign capital. Several parameters have influenced not only new threats, but also opportunities for organizations, under the influence of parameters such as technological disruptions, fluctuating economies and/or demographic changes. 
Changes in the global economic environment such as liberal economy, international competition, access to information and homogenization of culture are significant factors that have brought companies into a competitive position. Countries in transition are particularly interesting in this process, for which these types of mobilization of foreign capital are of great importance for their further accelerated development. Countries in transition still consider foreign direct investment a key instrument in the process of transforming their own economies. Due to the above, transition economies have become increasingly open to international operations, implementing the liberalization of economic relations with foreign countries in order to achieve greater competitiveness and attractiveness to attract foreign investors. Foreign investment refers to investment, where investors outside the country retain ownership rights and participate in management and control. FDI is often the most important form of foreign capital inflow from abroad into a country's economy in many countries. This is especially important for small and underdeveloped countries. FDI provides great mobility of capital, because today capital knows no boundaries (Zhang \& Chen, 2020). It certainly contributes to increasing economic activity, monitoring processes, adjusting and harmonizing business conditions, market positioning and great development potential, as well as better efficiency.

The effects of FDI are very complex when looking at the relationship between FDI and economic development. If viewed in this way (FDI), macroeconomic indicators generate better employment rates, better productivity, higher market competitiveness, technological progress and a generally better basis for the growth and development of a country's economy (Cicea \& Marinescu, 2020). They are especially important for underdeveloped countries, providing greater exports and access to international markets. FDIs generate productivity spillovers for the host economy. This is a consequence of the superior technologies possessed by multinational companies, with imported skills enhancing the marginal productivity of fixed capital in host countries, thus promoting economic growth and development. Foreign direct investments in 2019 amount to 699 million KM and are $26.6 \%$ lower compared to 2018. According to preliminary data from the Central Bank of $\mathrm{BiH}$ for the first half of 2020 , FDI is lower by $46.7 \%$ compared to the same period in 2019 (Central Bank of Bosnia and Herzegovina, 2020).

Foreign direct investment in less developed countries such as $\mathrm{BiH}$ will be under additional pressure in 2020/2021, due to the impact of the COVID 19 pandemic. The decline in global foreign direct investment in 2020 is estimated at $30-40 \%$ as a result of the pandemic. According to the index of economic freedoms for 2019, published by the prestigious American "The Heritage Foundation", Bosnia and Herzegovina ranks $83^{\text {rd }}$ in the world out of 180 ranked countries (The Heritage Foundation, 2019).

Viewed from the angle of economic freedoms, Bosnia and Herzegovina records a value of 62.9, which positions it in $82^{\text {nd }}$ place on the world list for 2021. Viewed from the angle of key parameters, its value increased by 0.3 points, thanks primarily to the improvement of the tax burden assessment. If we look at the European region, Bosnia and Herzegovina ranks $40^{\text {th }}$ out of 45 countries. Observed in the region, $\mathrm{BiH}$ is below average, as shown by FDI inflows, compared to the region. As the $\mathrm{BiH}$ economy has been hit by the crisis caused by the coronavirus pandemic, it is predicted that the economy will suffer a significant decline, which is already being felt (around 6.5\%, compared to the previous year). Already, FDI in $\mathrm{BiH}$ has been significantly reduced (The Heritage Foundation, 2021).

Stiglitz (1990) believes that companies in crisis are usually to blame for that (Stiglitz, 1990). There are many causes. The biggest untruth is that market mechanisms will lead to the solution of the problem on their own. Based on the above, a strategic approach to foreign direct investment in Bosnia and Herzegovina is necessary. The research hypothesis of the work is, H0: There is an impact of economic freedoms on foreign direct investment, which affects Bosnia and Herzegovina economic development, measured by gross domestic product. Economic globalization has meant that we have become more integrated, more interdependent, and that means that there is a greater need for collective action.

The methodological concept of the research includes an econometric model, which is based on the research period from 1998 to 2020. The model is based on multiple correlation analysis - Pearson Correlation. No modern economy can be isolated from the need to export and import capital, regardless of whether, overall, there is a net surplus or net capital deficit, so that the movement of capital between countries is two-way; within one 
case certain countries appear as donors and other times as users of capital.

\section{Review of the literature and previous research}

The fact is that domestic accumulation is not enough for stronger modernization of production and restructuring of certain economic branches, which would enable faster economic development and creation of internationally competitive domestic products. In such a situation, most transition countries consider foreign direct investment to be a key instrument in the process of transforming their own economies. Many factors help explain why FDI growth was particularly pronounced in transition countries. Intense competitive pressures in many industries have led companies to explore new ways to improve their competitiveness.

Kim (2010) considers that foreign direct investment is usually categorized as horizontal, vertical, and conglomerates (Kim, 2010). Horizontal direct investment implies a situation where an investor establishes the same type of business abroad because he operates in his own country. A vertical investment is one in which different but related business activities are established or purchased abroad from the main business of the investor. Bosnia and Herzegovina $(\mathrm{BiH})$ has placed its FDI policies in the context of market liberalization, foreign trade and capital movements, combined with the privatization of state capital in the economy as the most potent channel for attracting FDI. According to data of IBM Institute for Business Value (2019) published in the "Global Location Trends: 2019 Annual Report", $\mathrm{BiH}$ is ranked sixth in the world in terms of the number of jobs created under DSU projects per million inhabitants, and $\mathrm{BiH}$ is (IBM Institute for Business Value, 2019) third in terms of exportoriented investments. Unfortunately, the COVID19 pandemic will affect foreign direct investment in the world and expectations regarding the trend of foreign direct investment in $\mathrm{BiH}$. Although preliminary data for 2019 indicated the continuation of FDI growth and reaching a record value for the past ten years, the final data showed a decrease compared to 2018. In addition to the publication of data for 2019, the data for the previous two years were also revised. Foreign direct investments in 2018 are the largest annual inflow realized in the previous ten-year period.

Thanks to a long tradition, good development of the sector and natural resources, the most significant FDIs are invested in the manufacturing sector, about $35 \%$. The banking sector also has a significant share in the total inflow of foreign direct investment $(25 \%)$. In order to achieve FDI, strategic decisions of investors are necessary, as well as entities in $\mathrm{BiH}$ that need to create an environment for FDI. Strategic decisions imply long-term decisions related to the choice of where to invest and under what conditions (Falchetti, Cattani, \& Ferriani, 2021). Foreign investments are one of the most important parameters of the development of the modern economy and represent a platform for trade, organization of production and supply of goods and services. Therefore, decisions from this category are certainly from the category of strategic. Strategic decisions are unique and non-routine by their nature; they concern general goals, they are related to the most important issues and the broader picture of the entire company, they are related to strategies and they are very often unrepeatable and inevitable. FDI is an important factor in development, especially for developing countries (Osei \& Kim, 2020). Also, the situation is similar with transition countries. They are characterized by the aspiration for integration into the world economic system.

We can also say that economic freedoms imply that individuals make their own decisions, not under the influence of political processes, pressures of various kinds, or fraud (Gwartney, Hall, \& Lawson, 2017). There are several research studies on the impact of FDI on economic performance. Sovbetov and Moussa (2017) performed a systematization of studies (Sovbetov \& Moussa, 2017). Quazi (2007) made a significant contribution to this area, which indicates the importance of market potential and how open the country is to trade (Quazi, 2007). If we look at the structure of the index of economic freedoms, most of the literature deals with the study of the impact of the index of economic freedoms on FDI. From this point of view, the transparency of economic policies is a strategic issue for investors, especially for those committed to FDI. The positive correlation between economic freedoms, foreign direct investments and development is a consequence of market trends, resource allocation, better productivity, better production and business portfolio and profitability of investments. Given that FDI involves significant contingencies (especially the greenfield area), it is important to point out that investments depend on economic freedoms, legal certainty, economic stability and risk. Drabek and Payne (2001) pointed out that if 
there are specific economic policies related to foreign trade policy, these may be the key pillars of the platform for attracting FDI (Drabek \& Payne, 2001). The impact of globalization is also important here. According to Stiglitz (2008), economic globalization has meant that we have become more integrated, more interdependent, and that means that there is a greater need for collective action (Stiglitz, 2008). So far, several studies have been conducted on the relationship between economic freedom, economic development indicators, and FDI.

Based on their research, Pearson, Nyonna and Kim (2012) came to results that show a positive correlation between the parameters of economic freedoms and their impact on foreign direct investment in the United States (Pearson, Nyonna, \& Kim, 2012). According to Fofana (2014) results show the existence of the impact of economic freedoms on the movement of investments in the country, on a research sample of 25 Western European and 26 sub-Saharan countries (Fofana, 2014). The basis of this analysis was related to the parameters of economic freedoms, such as economies of scale, population, legal legislation and legal order, and others. The results of empirical research have shown that the aggregate index of economic freedom has no significant effect on FDI in Africa. One of the restrictions within his empirical study was insufficient observation number.

It is essential to mention the issue of responsibility for making a strategic decision. Without the implementation and realization of strategic decisions, they remain just "words on paper". The responsibility for the implementation of strategic decisions lies, no more and no less, than at all levels of management. In some theoretical and even practical approaches, only top managers at the top of the organization are considered to be responsible. According to the broader understanding, their main responsibility is related to social responsibility (respect for social responsibility and other related issues) and the general strategy related to achieving the goals of the entire organization. According to Nordhaus (1969), growth can be provided on the basis of knowledge that is growing exogenously (Nordhaus, 1969). Nordhaus (2018) stated that the economic growth rate of $3 \%$, compared to the previous year, is a continuation of the economic recovery trend (Nordhaus, 2018). Hayrdaroglu (2016) analysed the BRICS countries in the period 1995-2013, and came up with new scientific truths that indicate that economic freedoms are positively linked to economic growth, and FDI is positively linked to economic growth (Hayrdaroglu, 2016). This research results show a negative correlation between government size and economic growth.

Kurečić and Kokotović (2017) investigated the connection between political stability and foreign direct investments in small economies and the results show the existence of a positive correlation (Kurecic \& Kokotovic, 2017). Also in this study, a part of the analysis related to large and developed countries was missing. Gregory, Romer and Weil (1992) state that a significant contribution to economic growth was recorded in the retail and manufacturing industries, which had an impact on the increase in employment compared to the previous year (Gregory, Romer, \& Weil, 1992). Trade relations research has been the focus of many researchers, and the most significant ones are below. The results of Johnson's research (1953) show the interdependence and modelling of tariffs between the two countries (Johnson, 1953; see also Riezman, 1982; Kennan \& Riezman, 1988; Grossman \& Helpman, 1994). Mayer (1981) and Riezman (1982) explored the relationship of trade agreements based on negotiations between the two countries, which generates conditions for foreign direct investment (Mayer, 1981; Riezman, 1982). Positive effects from FDI inflows are also related to the "increase in labour productivity through technological transfers, management and marketing proficiency that enables long-term technological progress and economic growth" (Boghean \& State, 2015). On institutional quality, Estrin (2017) in her research came to results that show the positive impact of FDI on the labour market (Estrin, 2017). In their research endeavours, Zongzheng and Mao (2019) assess the importance of tax incentives for investments (Zongzheng \& Mao, 2019).

Macroeconomic variables have a significant impact on the attraction of foreign investment in highly developed countries then in developing countries (Walsh \& Yu, 2010, p. 24). Economic freedom implies the existence of a market economy based on free competition, protection of human rights and their property, as well as voluntary exchange (Caetano \& Caleiro, 2009). Ferreira, Carreira, Li and Serra (2016) investigated the relationship of economic freedoms, through factors of corruption to foreign direct investment in a market economy (Ferreira, Carreira, Li, \& Serra, 2016). 
The experiences of a large number of countries have shown that foreign direct investment is a more favourable channel for the inflow of necessary foreign accumulation compared to taking classic loans on the international financial market. Viewed from the macro aspect, the advantages of foreign direct investments are reflected in the following: the country's trade and balance of payments improve, the domestic economy fits faster and more efficiently on the world market, the domestic market supply improves and the number of new jobs increases. At the micro level, domestic companies have the following benefits: they get to modern technology faster and cheaper, they introduce more modern work organization, they acquire more modern knowledge in the field of market processing, etc.

The importance of foreign direct investment in developing countries is growing significantly, and in this regard, the creation and modelling of a strategic approach is becoming a research focus. In this regard, the number of research studies investigating the role and importance of FDI, as a strategic resource for the development of small and underdeveloped countries, increasing productivity, technological progress and a better business environment is growing (Sekkat \& VeganzonesVaroudakis, 2007). Issues of economic freedom are increasingly occupied by the research space, given its effects on the level of trust of agents, as well as the level of strategic decisions on FDI (Voyer \& Beamish, 2004).

\section{Research methodology and sampling}

According to the United Nations Conference on Trade and Development (2020), investors are guided by two strategies, the amount of foreign direct investment decreases in developed countries and shifts to developing countries, which contributes to their growth (United Nations Conference on Trade and Development, 2020). The next strategy that investors apply refers to the trend, to indirectly reach cheaper resources and cheaper labour through quality FDI. In underdeveloped countries, the development of production capacities certainly contributes to the development of the economies of those countries. Some studies show the existence of subjectivity parameters, which includes fuzzy logic clustering (Caetano \& Caleiro, 2009). The period of the research scope covers the period 1998-2020 years. The Heritage Economic Freedom Index platform is created by The Heritage Foundation and The Wall
Street Journal, and its platform is built by 10 pillars, business freedoms, trade freedoms, fiscal parameters, public spending, monetary factors, investments, funding sources, legal issues, corruption and human resources, and the parameters range from 0-100. Each of the previously listed parameters influences strategic decisions on foreign direct investment. It is necessary to perform modelling and strategic positioning, where the starting point of the model platform is the expression $(\mathrm{Y}=\mathrm{a}+\mathrm{bX}$ or $\mathrm{Y}=\mathrm{b} 0+$ $\mathrm{b} 1 \mathrm{X}$ ), which is the basis of linear programming and modelling. If we have more variables and parameters that are stochastic or deterministic in nature, it is possible to create more complex models of the second, third or fourth degree, such as $(\mathrm{Y}=\mathrm{a}+\mathrm{bX}+\mathrm{cX} 2)$ (Draper \& Smith, 1998). Then, in modelling a multiple regression model, Y is a normally distributed variable (Draper \& Smith, 1998):

\section{$Y=\beta_{0}+\beta_{1} X_{1}+\ldots+\beta \rho X \rho+\sigma(Y), \operatorname{sd}(Y)=$ $\sigma$ (independent of $X$ 's)}

$\mathrm{Y}$ - dependent variable (indicator of mathematical relation and relations of independent and dependent variables (economic development of Bosnia and Herzegovina, measured by GDP)). The variables of the multiple linear regression model in the above form, express the average regular, quantitative relationship between the dependent variable $Y$ and $\rho$ of the independent variables, $\beta_{0}+$ $\beta_{1}+\ldots+\beta_{\rho}$. These variables, in essence, represent estimates of the parameters of the regression model.

The variables of the model $\beta 0+\beta 1+\ldots+\beta \rho$ and $\sigma$ are the result of in-depth analysis and research of available data.

$\beta 0=$ variable of the zero model, and shows the level of relative importance

$\beta_{1}, \beta_{\rho}=$ regression coefficients, show the relative assessments of the development of the economy of Bosnia and Herzegovina for the unit change of variables of economic freedoms and foreign direct investment

$\sigma=\sigma_{\text {res }}=$ residual standard deviation

$\beta 1$ - model platform parameter, which implies the mean increase of $Y$ based on the unit increase of parameter $\mathrm{Xi}$, while the other parameters remain fixed. This means that it is equal to the mean increase in $\mathrm{Y}$ per unit of increase of $\mathrm{Xi}$, while the other $\mathrm{Xi}$ are kept fixed. $\beta \mathrm{i}$ correction factor is factor $\mathrm{Xi}$ for other parameters $\mathrm{X}$. The solution is reduced to the least squares model. According to Draper \& 
Smith (1998) the partial correlation coefficient is given in the following form (Draper \& Smith, 1998):

$$
R_{Y / X_{1} X_{2}}^{2}=\frac{r_{x_{1} y}^{2}+r_{x_{2} y}^{2}-2 r_{x_{1} y} r_{x_{2} y} r_{x_{1} x_{2}}}{1-r_{x_{1} x_{2}}^{2}}
$$

$$
r_{y x_{1} \cdot x_{2}}=\frac{r_{y x_{1}}-r_{y x_{2}} \cdot r_{x_{1} x_{2}}}{\sqrt{1-r_{y x_{2}}^{2}} \sqrt{1-r_{x_{1} x_{2}}^{2}}}
$$
below.

The model of econometric analysis is given

\begin{tabular}{|c|c|c|c|c|c|c|c|c|c|c|c|c|c|}
\hline Index & 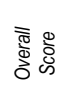 & 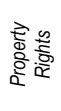 & 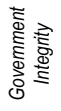 & 离岕 & 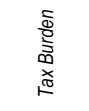 & 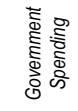 & $\begin{array}{l}\overline{\mathbb{w}} \mathbf{5} \\
\text { 通 }\end{array}$ & 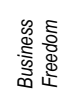 & 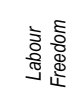 & 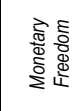 & 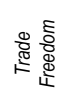 & 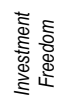 & 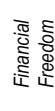 \\
\hline 1998 & 29.40 & 10.0 & 10.0 & N/A & 78.8 & 16.7 & $\mathrm{~N} / \mathrm{A}$ & 40.0 & $\mathrm{~N} / \mathrm{A}$ & 0.0 & 69.4 & 30.0 & 10.0 \\
\hline 1999 & 29.40 & 10.0 & 10.0 & N/A & 78.8 & 16.70 & $\mathrm{~N} / \mathrm{A}$ & 40.0 & $N / A$ & 0.0 & 69.4 & 30.0 & 10.0 \\
\hline 2000 & 45.10 & 10.0 & 10.0 & $N / A$ & 82.0 & 52.0 & $\mathrm{~N} / \mathrm{A}$ & 40.0 & $\mathrm{~N} / \mathrm{A}$ & 83.3 & 69.0 & 30.0 & 30.0 \\
\hline 2001 & 36.60 & 10.0 & 10.0 & $\mathrm{~N} / \mathrm{A}$ & 67.0 & 0.0 & $\mathrm{~N} / \mathrm{A}$ & 40.0 & $\mathrm{~N} / \mathrm{A}$ & 75.2 & 67.6 & 30.0 & 30.0 \\
\hline 2002 & 37.40 & 10.0 & 10.0 & $\mathrm{~N} / \mathrm{A}$ & 66.8 & 0.0 & $\mathrm{~N} / \mathrm{A}$ & 40.0 & $N / A$ & 77.2 & 72.6 & 30.0 & 30.0 \\
\hline 2003 & 40.60 & 10.0 & 10.0 & N/A & 66.1 & 3.2 & $\mathrm{~N} / \mathrm{A}$ & 40.0 & $\mathrm{~N} / \mathrm{A}$ & 77.9 & 78.2 & 30.0 & 50.0 \\
\hline 2004 & 44.70 & 10.0 & 10.0 & $\mathrm{~N} / \mathrm{A}$ & 70.1 & 18.3 & $N / A$ & 40.0 & $\mathrm{~N} / \mathrm{A}$ & 82.4 & 71.8 & 30.0 & 70.0 \\
\hline 2005 & 48.80 & 10.0 & 33.0 & $\mathrm{~N} / \mathrm{A}$ & 70.1 & 23.8 & $\mathrm{~N} / \mathrm{A}$ & 40.0 & 54.8 & 84.5 & 71.8 & 30.0 & 70.0 \\
\hline 2006 & 55.60 & 10.0 & 31.0 & $\mathrm{~N} / \mathrm{A}$ & 75.1 & 47.8 & $\mathrm{~N} / \mathrm{A}$ & 55.7 & 54.9 & 86.1 & 75.2 & 50.0 & 70.0 \\
\hline 2007 & 54.40 & 10.0 & 29.0 & $\mathrm{~N} / \mathrm{A}$ & 74.9 & 47.8 & $\mathrm{~N} / \mathrm{A}$ & 55.4 & 53.8 & 82.5 & 80.2 & 50.0 & 60.0 \\
\hline 2008 & 53.90 & 10.0 & 29.0 & $\mathrm{~N} / \mathrm{A}$ & 73.7 & 48.3 & $\mathrm{~N} / \mathrm{A}$ & 57.2 & 54.2 & 76.6 & 79.8 & 50.0 & 60.0 \\
\hline 2009 & 53.10 & 10.0 & 33.0 & $\mathrm{~N} / \mathrm{A}$ & 71.8 & 37.6 & $\mathrm{~N} / \mathrm{A}$ & 59.9 & 52.1 & 79.0 & 77.2 & 50.0 & 60.0 \\
\hline 2010 & 56.20 & 10.0 & 32.0 & $\mathrm{~N} / \mathrm{A}$ & 83.2 & 28.8 & $\mathrm{~N} / \mathrm{A}$ & 61.3 & 61.2 & 74.7 & 80.8 & 70.0 & 60.0 \\
\hline 2011 & 57.50 & 20.0 & 30.0 & $\mathrm{~N} / \mathrm{A}$ & 83.9 & 24.1 & $\mathrm{~N} / \mathrm{A}$ & 60.4 & 60.2 & 80.6 & 86.0 & 70.0 & 60.0 \\
\hline 2012 & 57.30 & 20.0 & 32.0 & N/A & 84.3 & 24.4 & $\mathrm{~N} / \mathrm{A}$ & 55.2 & 60.4 & 80.7 & 86.0 & 70.0 & 60.0 \\
\hline 2013 & 57.30 & 20.0 & 32.0 & $\mathrm{~N} / \mathrm{A}$ & 83.2 & 26.9 & $\mathrm{~N} / \mathrm{A}$ & 54.3 & 61.2 & 79.0 & 86.4 & 70.0 & 60.0 \\
\hline 2014 & 58.40 & 20.0 & 33.9 & $N / A$ & 82.9 & 27.4 & $\mathrm{~N} / \mathrm{A}$ & 55.5 & 62.4 & 80.1 & 86.9 & 75.0 & 60.0 \\
\hline 2015 & 59.00 & 20.0 & 42.0 & $\mathrm{~N} / \mathrm{A}$ & 82.9 & 27.3 & $\mathrm{~N} / \mathrm{A}$ & 53.5 & 63.4 & 84.0 & 87.2 & 70.0 & 60.0 \\
\hline 2016 & 58.60 & 20.0 & 39.0 & $\mathrm{~N} / \mathrm{A}$ & 83.9 & 33.1 & $\mathrm{~N} / \mathrm{A}$ & 54.6 & 59.4 & 84.3 & 87.0 & 65.0 & 60.0 \\
\hline 2017 & 60.20 & 41.2 & 32.7 & 40.0 & 83.5 & 33.7 & 89.3 & 47.4 & 59.3 & 84.0 & 86.6 & 65.0 & 60.0 \\
\hline 2018 & 61.40 & 39.5 & 28,4 & 43.7 & 83.5 & 41.5 & 94.4 & 49.3 & 59.6 & 83.5 & 87.8 & 65.0 & 60.0 \\
\hline 2019 & 61.90 & 40.2 & 30.2 & 37.9 & 84.3 & 46.1 & 96.6 & 49.7 & 67.0 & 83.1 & 82.6 & 65.0 & 60.0 \\
\hline 2020 & 62.60 & 44.4 & 41.8 & 33.9 & 83.6 & 49.3 & 97.3 & 45.7 & 67.4 & 82.7 & 80.0 & 65.0 & 60.0 \\
\hline
\end{tabular}

Table 1 Economic Index of Freedoms of Bosnia and Herzegovina (1998-2020)

Based on the previous data, the movement of the index of economic freedoms and variables that build a given platform is visible. Also, the movement of the index of economic freedoms from 1998 is visible, from when the index of economic freedoms is calculated until 2019 and 2020 (the years affected by the corona virus COVID 19). The analysis is given below. 
Table 2 Movement of foreign direct investment (FDI) and gross domestic product (GDP) of Bosnia and Herzegovina in the period $1998-2020$

\begin{tabular}{|c|c|c|}
\hline Years & GDP (million \$) & FDI (million \$) \\
\hline 1998 & $4,116,699,437.40$ & $66,736,468.36$ \\
\hline 1999 & $4,685,733,115.47$ & $176,780,594.76$ \\
\hline 2000 & $5,505,887,894.49$ & $146,075,610.88$ \\
\hline 2001 & $5,748,993,411.42$ & $118,495,219.81$ \\
\hline 2002 & $6,651,106,833.49$ & $267,769,568.96$ \\
\hline 2003 & $8,369,878,822.85$ & $381,784,637.39$ \\
\hline 2004 & $10,596,205,714.29$ & $889,597,294.55$ \\
\hline 2005 & $11,222,953,519.43$ & $623,812,851.56$ \\
\hline 2006 & $12,864,610,993.52$ & $845,962,876.36$ \\
\hline 2007 & $15,778,767,669.70$ & $1,841,972,230,25$ \\
\hline 2008 & $19,112,739,664.47$ & $1,004,852,659,85$ \\
\hline 2009 & $17,613,836,209.96$ & 138.511 .019 .73 \\
\hline 2010 & $17,176,781,336.76$ & $443,840,207.09$ \\
\hline 2011 & $18,644.723 .860 .97$ & $471,610,992.22$ \\
\hline 2012 & $17,226.849 .297 .07$ & $391,976,946.38$ \\
\hline 2013 & $18,178,503,835.45$ & $313,295,008.33$ \\
\hline 2014 & $18,558,343,508.34$ & $544,866,345.46$ \\
\hline 2015 & $16,211,541,820.24$ & $383,089,615.73$ \\
\hline 2016 & $16,913,330,693.97$ & $313,198,153.36$ \\
\hline 2017 & $18,080,118,128.39$ & $509,429,047.92$ \\
\hline 2018 & $20,183,510,561.26$ & $594,804,957.64$ \\
\hline 2019 & $20,164,193,806.88$ & $390,210,690.89$ \\
\hline 2020 & $19,389,000,000.00$ & $273,147,483.63$ \\
\hline
\end{tabular}

Source: the World Bank, 2021

The data in the table above show a trend of GDP growth in the observed period. The inflow of funds through FDI is not only an inflow of capital, but a basis for increasing trade flows, economic growth and development and job creation. The movement of FDI is influenced by several macroeconomic, socio-political, corporate and technological factors. A study conducted by UNCTAD in the early 2017 and involving CEOs of the world's leading companies listed as the most significant factors influencing FDI flows: the economic situation of Asian developing countries, the state of the US economy, the economic situation in the European Union, oil prices, changes in tax regimes, exchange rate volatility and rising interest rates. Most respondents saw technological change and the digital economy as positive factors driving cross-border investment, despite the risk of cyberattacks and data security.

\section{Findings}

The following research results were obtained based on the input parameters (Table 3).

Based on previous econometric research and analysis, we can conclude that there is a significant correlation between economic freedoms and GDP in Bosnia and Herzegovina (0.940527792). This trend is mostly dependent on Trade Freedom, Tax Burden and Monetary Freedom, thus partially confirming our research hypothesis of Ho's work. The second part of the analysis shows that there is a correlation between economic freedoms and FDI in Bosnia and Herzegovina, but it is not significant (0.291401437 and 0.071961395). This is a consequence of many other parameters that determine FDI in Bosnia and Herzegovina, such as country risk and others. Graphical representations of models and research are also given below. The research model with the results is given below (Figure 1).

Model - Strategic decision making and influence of economic freedoms on foreign direct investment (FDI) in Bosnia and Herzegovina, becomes an important factor in strategic decision making. 
Milovanović \& Marković. Strategic decision making and influence of economic freedoms on foreign direct investment

(FDI) in Bosnia and Herzegovina

Table 3 Results of the econometric model research

\begin{tabular}{|c|c|c|c|}
\hline & Index Score & FDI (million \$) & GDP ( million \$) \\
\hline Observations & 23 & 23 & 23 \\
\hline Mean & 51.2783 & $483,992,194.8306$ & $14,043,230,875.4701$ \\
\hline Stdevp & 10.0608 & $377,169,704.4837$ & $5,472,830,656.8289$ \\
\hline Variance & 101.2200 & $\begin{array}{r}142,256,985,980,327,000.000 \\
0 \\
\end{array}$ & $\begin{array}{r}29,951,875,398,326,300,000.000 \\
0\end{array}$ \\
\hline Coefficient of variation & 0.1962 & 0.7793 & 0.3897 \\
\hline Median & 55.6000 & $390,210,690.8934$ & $16,913,330,693.9653$ \\
\hline Max & 62.6000 & $1,841,972,230.2525$ & $20,183,510,561.2553$ \\
\hline Min & 29.4000 & $66,736,468.3604$ & $4,116,699,437.4041$ \\
\hline Coefficient of determination-one & 0.084914798 & 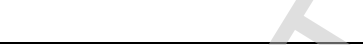 & \\
\hline Coefficient of determination-two & & 0.884592528 & sen \\
\hline Coefficient of determination-three & & & 0.088480479 \\
\hline Pearson Correlation-one & 0.291401437 & 2 & \\
\hline Pearson Correlation-two & & 0.940527792 & \\
\hline Pearson Correlation-three & & & 0.297456685 \\
\hline Correlation & 0.071961395 & 0.071961395 & 0.071961395 \\
\hline$(1-\alpha)$ & 0.95 & 0.95 & 0.95 \\
\hline a & 0.05 & 0.05 & 0.05 \\
\hline
\end{tabular}

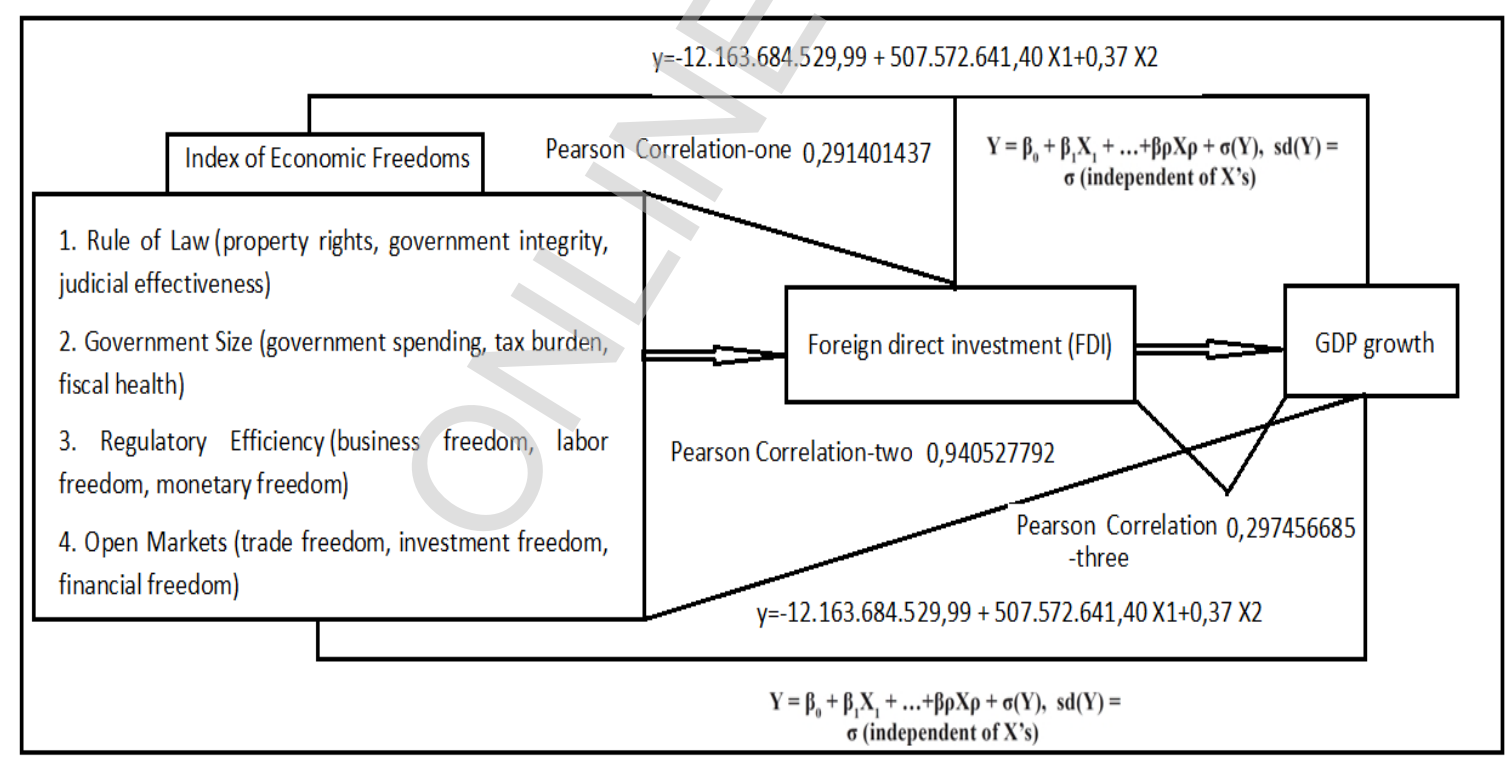

Figure 1 Model - Strategic decision making and influence of economic freedoms on foreign direct investment (FDI) in Bosnia and Herzegovina

Source: the authors' own research

\section{Discussion}

Based on the modelling of the platform and the conducted research and analysis, we came to the knowledge about the existence of a significant impact of economic freedoms on GDP growth in
Bosnia and Herzegovina. Also, the results of the research show that foreign direct investments depend on other factors and that economic freedoms are not the dominant factor in strategic decision-making, on investing in the $\mathrm{BiH}$ economy. 
According to this analysis, foreign direct investments also depend on other parameters, such as country risk, trust, experiences of other countries, influences of informal groups and others. The results of the research are comprehensive, from the beginning of the calculation of economic freedoms for Bosnia and Herzegovina until today. The lack of a significant correlation between economic freedoms and foreign direct investment was especially pronounced during the coronavirus pandemic, when investors withdrew, regardless of the parameters of economic freedoms. This is proof of the vulnerability of Bosnia and Herzegovina's economy. For example, if we look at a similar comparison with the Chinese economy, where there is a significant correlation between economic freedoms on FDI and GDP growth, their economy withstood the crisis more easily, and also recovered very quickly. In general, only a strategic approach and way of thinking can balance and establish the above correlation to the higher level, which will affect the growth of the economy of Bosnia and Herzegovina.

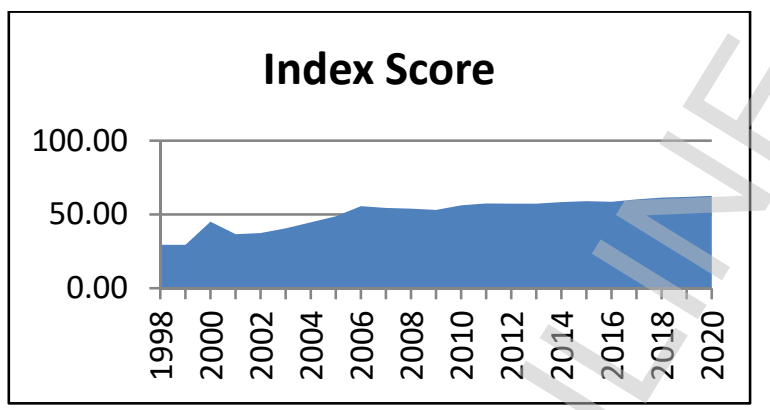

Figure 2 Movement and impact of economic freedoms in Bosnia and Herzegovina (1998-2020) Source: the authors' own research

Observed historically from the period when economic freedoms in $\mathrm{BiH}$ began to be counted, we can say that there is a constant progress, which can be seen in the previous chart. If we look at the analysis and research, we can see that although the historical trend shows a small impact on FDI, the ratio, which represents this indicator, is improving. If we look at 1998 and 1999, we can see that today, in 2021, the value of economic freedoms is twice as high. This should certainly give confidence to foreign direct investors. If we look at the trend of the last five years, we can see that there has been an increase in this parameter by 1,232 points. The current assessment is at the level of moderate economic freedom. In order to increase the parameter of economic freedoms, it is necessary to increase the values of parameters such as property rights, judicial efficiency and the integrity of the government. For further improvements of this parameter, a high level of economic, social and political integration and harmonization at all levels is necessary. This will certainly be important in the future, in the conditions of the coronavirus and the COVID 19 pandemic (The Heritage Foundation, 2021).

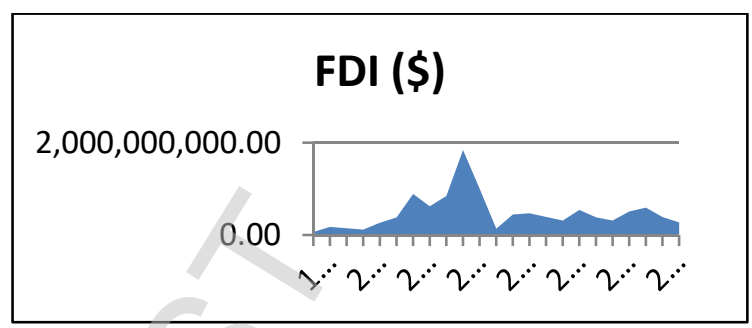

Figure 3 Movement and impact of foreign direct investment (FDI) in Bosnia and Herzegovina (1998-2020) Source: the authors' own research

Indicators of the business environment and competitive position point to the conclusion that there is a strong need to implement structural reforms that would ensure an increase in the growth rate of $\mathrm{BiH}$ economy. The seriousness of this problem was also recognized by $\mathrm{BiH}$. Authorities that have shown commitment through the Reform Agenda and have begun to take action to improve the business environment. Thus, they established the Agency for the Promotion of Foreign Investments (FIPA), in addition to FIPA, there is also the Foreign Trade Chamber of $\mathrm{BiH}$, which operate jointly with the relevant ministries and agencies. Although Bosnia and Herzegovina has strategies for attracting FDI, they are still not adequately organized. The COVID-19 pandemic presents a major challenge for strategic decisionmaking on FDI, especially in small underdeveloped countries. This was reflected through a reduction in the supply of raw materials, middle entrances and final goods. If we look at the experiences of the developed, we can see that the governments of many countries are applying measures to eliminate bottlenecks in the supply chain, such as China, the developed countries of Europe and the United States. The consequences of COVID-19 have affected many countries, and have particularly affected developing countries and small open economies that are highly vulnerable to market and trade fluctuations, such as Bosnia and Herzegovina. 


\subsection{Theoretical and practical implications}

The paper investigates the impact of the strategic concept with two independent variables (economic freedoms and foreign direct investments) on the economic development of Bosnia and Herzegovina. Theoretical implications relate to the strategic decision-making model and the impact of research variables on economic development. All the most important, scientifically proven and empirically confirmed benefits from the application of the concept of strategic decision making are systematized, as well as the most important parameters of its improvement. The cause-and-effect relationship between independent and dependent research variables is explained. The model includes 12 research subvariants that build an index of economic freedoms, which can be individually modelled and measure their impact on foreign direct investment and strategic decisionmaking, as well as the development of Bosnia and Herzegovina measured on the basis of GDP. Also, the influence of all individual parameters of the index of economic freedoms is incorporated into the basic model, which is a research contribution. The practical contribution is reflected in the results of the application of the model to Bosnia and Herzegovina. The results of the practical research confirmed the research hypothesis of the paper. The practical implementation is also reflected in pointing out the importance of applying the model, especially from the point of view of Bosnia and Herzegovina, which should work on improving economic freedoms.

The outbreak of the COVID-19 pandemic has caused a number of negative economic consequences that threaten the decline in gross domestic product (GDP), employment, public revenues, investment and exports. On a global scale, the pandemic has caused two effects - a fall in the value of stock indices and a fall in oil prices, which in this accident could alleviate the balance of BiH's difficulties.

At the centre of events are multinational corporations - companies whose top management makes strategic investment decisions on FDI in other companies and countries. Many of them have made decisions to relocate and relocate their production to other countries and other markets, which has significantly influenced the recomposition of the global value chain in the world in the last three decades. Some of the most important sectors are certainly the automotive industry, IT sector, electrical equipment, petroleum products and energy, chemical and pharmaceutical industry, etc.

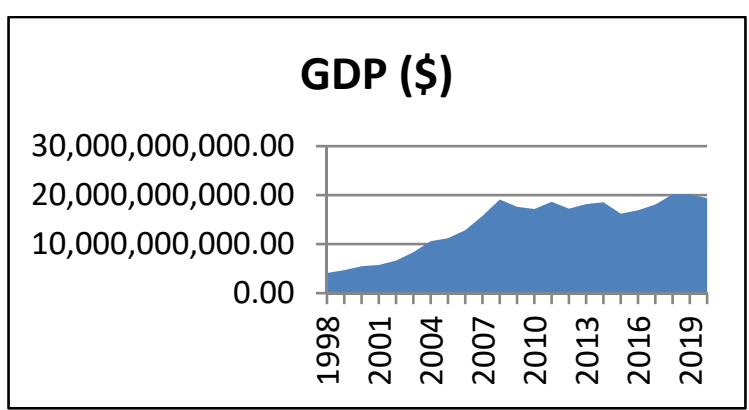

Figure 4 Movement and impact of gross domestic product (GDP) in Bosnia and Herzegovina (1998-2020) Source: the authors' own research

If we look historically, there is a trend of GDP growth. In 2020, there is a decline caused by COVID 19 conditions. Different tax policies have led to different tax rates, which range around 10\%. The total tax is around $20.4 \%$ percent of total domestic income. If we look at macroeconomic indicators, we see that public spending was at around $41 \%$ of GDP, and a budget surplus of $2 \%$ of GDP was created.

\subsection{Limitations of the study}

Analysing the sampling flow, the existence of difficulties in conducting the research is visible. Further impact analysis is limited to obtaining additional data. One of the limiting factors of research is certainly the cost of research, where much larger financial resources are needed to conduct implicit research. Also, the availability of data for a wider time frame of the research. The Index of Economic Freedoms has been calculated for Bosnia and Herzegovina only since 1998.

\subsection{Direction for future research}

The directions of further research activities will largely depend on the nature and severity of the problems that companies face in their business. The emergence of the global COVID 19 crisis, caused by the coronavirus, will greatly affect major changes, especially in the field of foreign direct investment in Bosnia and Herzegovina and strategic decisions, as well as the level of economic freedoms. One of the directions of further research would refer to the sectoral analysis and areas in which the impact of economic freedoms is more important on foreign direct investment, and thus the development of Bosnia and Herzegovina. Also, 
the direction of further research could certainly go in the direction of exploring the impact of intuition of business decision makers on economic development, based on economic freedoms and foreign direct investment.

\section{Conclusion}

Attracting foreign investors is a priority for a large number of countries, especially those in development. "Most countries in transition have established Investment Promotion Agencies (IPAs) in the 1990s and have adopted strategies to attract them. These strategies included the opening of state ownership to foreign investment, especially in infrastructure and services (Slovenia), the provision of tax and state incentives and financial support to investors in certain regions or industries (Hungary and the Czech Republic), income tax relief and customs relief on high-tech imports (Slovakia). Tax incentives are very important for FDI, because foreign investors opt for the country that has lower taxes. In order to attract foreign investment, attraction policies (strategies) are needed that include programs to improve workforce skills and take advantage of increased competition. Various activities are being undertaken to attract foreign capital (Busenbark, Semadeni, Arrfelt, \& Withers, 2021).

Some of them are changes in national laws, financial measures aimed at reducing taxes and providing various financial incentives. Investors care about the social and political environment, ease of doing business, quality and reliability of infrastructure and utilities, and the possibility of employing professional and educational workers. The strategy for attracting FDI includes improving the investment environment, legislative and institutional framework, removing administrative barriers to investment, strengthening the investment potential of the SME sector by joining global value chains, adapting education and the labour market to the needs of investors, creating a supportive environment for investment in research, development, innovation and KET technologies, strengthening investment potential in the tourism sector, development of regional infrastructure, promotion of $\mathrm{BiH}$ as a desirable investment destination and development of the country's investment profile by sectors, implementation of communication strategy to encourage investment, development of a plan to attract greenfield investments in export-oriented sectors, in emerging industries and high-tech sectors, and attracting greenfield investments, developing a plan for the implementation of brownfield investments by placing in the state asset function, investor support in all phases of investment project implementation, financial frameworks for strategies and action plan for strategies.

Looking at 2020 and the constraints on supply and demand, and in general the intention to reduce FDI in $\mathrm{BiH}$, it is expected that in 2021 , under the influence of COVID-19, FDI will be reduced by $30 \%-40 \%$. This will have a negative impact on the leading sectors in $\mathrm{BiH}$. In certain areas, revenue is expected to fall above $100 \%$. The reason for this is the fact that reinvested earnings from previous FDI will also be absent. How the economy will develop further in the COVID-19 era depends on estimates of the course of the pandemic. The world-famous consulting firm McKinsey developed two scenarios of the global flow of the economy during the COVID-19 era. The first is a belated recovery scenario in which Europe and the US experience a peak in late April and a decline in June 2020. China and Asian countries are recording recovery and virus control in the late first quarter or early second quarter. In economic terms, this scenario predicts a decline in consumption, investment, unemployment and a large number of bankruptcies with consequences for the financial system. The recession disappears in the fourth quarter of 2020, which was partially realized. The second scenario is a prolonged contraction scenario in which Europe and the US control the virus in the early 2020s. However, it is confirmed that COVID-19 is not of a seasonal character; it lasts throughout the year. After a deep recession and numerous bankruptcies, the recovery occurs in the US and Europe in the $2^{\text {nd }}$ quarter of 2021, and in China in the $1^{\text {st }}$ quarter of 2021. Based on these two scenarios, it is clear that the $\mathrm{BiH}$ economy is entering a recession as a result of exclusively external factors, i.e. it will hit both efficient and productive and well-positioned export and domestic companies. The recession will have its own sectoral and socio-cluster characteristics. The research hypothesis of the work is, $\mathrm{H} 0$ : There is an impact of economic freedoms on foreign direct investment, which affects Bosnia and Herzegovina economic development, measured by gross domestic product, which is partially confirmed $(0,071961395)$. From the point of view of economic freedoms, Bosnia and Herzegovina is still at a low level compared to the world's leading economies. This is often the reason for insufficient trust in the economy of Bosnia and Herzegovina and often a factor influencing foreign direct 
Milovanović \& Marković. Strategic decision making and influence of economic freedoms on foreign direct investment

(FDI) in Bosnia and Herzegovina

investment.

Strategic decisions are most important here. As we can see, the result of the strategic decisionmaking process is strategic decisions. In order for them to be valorised, it is necessary to take certain actions based on those decisions. The action dimension implies that strategic management arises from the concept of strategic planning. On the other hand, planning and thinking alone will not be expedient unless they are followed by concrete action to achieve the goals. Strategic decisions and strategic thinking will certainly be the basis for improvements, development of the $\mathrm{BiH}$ economy and attracting foreign direct investment (FDI) in the future.sm

\section{References}

Boghean, C., \& State, M. (2015). The relation between foreign direct investments (FDI) and labour productivity in the European Union countries. Procedia Economics and Finance, 32, 278-285.

https://doi.org/10.1016/S2212-5671(15)01392-1

Busenbark, R. J., Semadeni, M., Arrfelt, M., \& Withers, C. M. (2021). Corporate-level influences on internal capital allocation: The role of financial analyst performance projections. Strategic Management Journal, 43(1), 180209. https://doi.org/10.1002/smj.3331

Caetano, J., \& Caleiro, A. (2009). Economic freedom and foreign direct investment: How different are the MENA countries from the EU. IBusiness, 1(2), 65-74. https://doi.org/10.4236/ib.2009.12010

Central Bank of Bosnia and Herzegovina. (2020). Statistics. Sarajevo, Bosnia and Herzegovina. Retrieved October 7, 2021, from https://www.cbbh.ba/Content/Read/8

Cicea, C., \& Marinescu, C. (2020). Bibliometric analysis of foreign direct investment and economic growth relationship. Journal of Business Economics and Management, 22(2), 445-466. https://doi.org/10.3846/jbem.2020.14018

Drabek, Z., \& Payne, W. (2001). The impact of transparency on foreign direct investment. World Trade Organization - Economic Research and Analysis Division, Working Paper ERAD-99-02. Retrieved October 2021, from http://www.wto.org/english/res e/reser e/wpaps e.htm

Draper, N. R., \& Smith, H. (1998). Applied Regression Analysis, Third Edition. New York: Wiley. https://doi.org/10.1002/9781118625590

Estrin, S. (2017). Foreign direct investment and employment in transition economies. IZA World of Labor, 301-330. https://doi.org/10.15185/izawol.330

Falchetti, D., Cattani, G., \& Ferriani, S. (2021). Start with "Why", but only if you have to: The strategic framing of novel ideas across different audiences. Strategic Management Journal, 43(1), 130-159. https://doi.org/10.1002/smj.3329

Ferreira, M., Carreira, H., Li, D., \& Serra, F. (2016). The moderating effect of home country corruption on the host country's ability to attract FDI. Brazilian Business Review, 13(4), 94-117. https://doi.org/10.15728/bbr.2016.13.4.5
Fofana, M. F. (2014). The influence of measures of economic freedom on FDI: A comparison of western europe and Sub-Saharan Africa. Global Economy Journal, 14(03n04), 399-424. https://doi.org/10.1515/gej-2014-0023

Gregory, N. M., Romer, D., \& Weil, D. N. (1992). Contribution to the empirics of economic growth. The Quarterly Journal of Economics, 107(2), 407-437. https://doi.org/10.2307/2118477

Grossman, G. M., \& Helpman, E. (1994). Protection for Sale. A.E.R. , 833-850.

Gwartney, J., Hall, J., \& Lawson, R. (2017). Economic freedom of the world: 2017 annual report. Retrieved April 2018, from https://www.fraserinstitute.org/studies/economicfreedom-of-the-world-2017-annual-report

Hayrdaroglu, C. (2016). The effect of foreign direct investment and economic freedom on economic growth: The case of BRICS countries. Research in World Economy, 7(1), 1-10. https://doi.org/10.5430/rwe.v7n1p1

IBM Institute for Business Value. (2019). Global Location Trends: 2019 Annual Report. Armonk, NY 10504, United States of America. Retrieved 12 2020, from https://www.ibm.com/thought-leadership/institutebusiness-value/report/gltr2019

Johnson, H. (1953). Optimum tariffs and retaliation. The Review of Economic Studies, 21(2), 142-153. https://doi.org/10.2307/2296006

Kennan, J., \& Riezman, R. (1988). Do big countries win tariff Wars? International Economic Review, 29(1), 8185.

https://doi.org/10.2307/2526808

Kim, H. (2010). Political stability and foreign direct investment. International Journal of Economics and Finance, 2(3), 59-71. https://doi.org/10.5539/ijef.v2n3p59

Kurecic, P., \& Kokotovic, F. (2017). The relevance of political stability on FDI: A VAR analysis and ARDL models for selected small, developed, and instability threatened economies. Economies, 5(3). https://doi.org/10.3390/economies5030022

Mayer, W. (1981). Theoretical considerations on negotiated tariff adjustments. Oxford Econ. Papers, 135-153. https://doi.org/10.1093/oxfordjournals.oep.a041494

Nordhaus, W. D. (1969). An Economic Theory of Technological Change. American Economic Review, 18-28.

Nordhaus, W. D. (2018). Evolution of modeling of the economics of global warming: Changes in the DICE model, 1992-2017. NBER Working Paper 23319. https://doi.org/10.1007/s10584-018-2218-y

Osei, M. J., \& Kim, C. J. (2020). Foreign direct investment and economic growth: IS more financial development better? Economic modelling, 93(C), 154-161. https://doi.org/10.1016/j.econmod.2020.07.009

Pearson, D., Nyonna, D., \& Kim, K. (2012). The relationship between economic freedom, state growth and foreign direct investment in US states. International Journal of Economics and Finance, 4(10), 140-147. https://doi.org/10.5539/ijef.v4n10p140

Quazi, R. (2007). Economic freedom and foreign direct investment in East Asia. Journal of the Asia Pacific Economy, 12(3), 329-344. https://doi.org/10.1080/13547860701405755 
Riezman, R. (1982). Tariff retaliation from a strategic viewpoint. Southern Econ. J., 583-593. https://doi.org/10.2307/1058652

Sekkat, K., \& Veganzones-Varoudakis, M. (2007). Openness, investment climate, and FDI in developing countries. Review of Development Economics, 11(4), 607-620. https://doi.org/10.1111/j.1467-9361.2007.00426.x

Sovbetov, Y., \& Moussa, M. (2017). Interaction of economic freedom and foreign direct investment globally: Special cases from neglected regions. Journal of Economics and Financial Analysis, 1(1), 59-80. https://doi.org/10.1991/jefa.v1i1.a4

Stiglitz, J. (1990). Some retrospective views on growth theory. U P. Diamond, Growth/ Productivity/ Unemployment (str. 50-68). Cambridge: MA: MIT Press.

Stiglitz, J. (2008). The need for an adequate international framework for FDI. U K. P. Sauvant, The Rise of Transnational Corporations from Emerging Markets (str. Chapter 15). Edward Elgar Publishing. https://doi.org/10.4337/9781848441460.00026

The Heritage Foundation. (2021). Statistics. Retrieved October 7, 2021, from https://www.heritage.org/index/heatmap

The World Bank. (2021). Data, Bosnia and Herzegovina. Retrieved October 7, 2021, from https://data.worldbank.org/country/bosnia-andherzegovina

\section{$\triangle$ Correspondence}

\section{Nenad Marković}

University of East Sarajevo, Faculty of Medicine

Studentska 5 St, 73300 Foca

Bosnia and Herzegovina

E-mail: markonen@ues.rs.ba
United Nations Conference on Trade and Development. (2020). Trade and development, report 2020. From global pandemic to prosperity for all: avoiding another lost decade. Geneva. Retrieved October 7, 2021, from https://unctad.org/system/files/officialdocument/tdr2020 en.pdf

Voyer, P., \& Beamish, P. (2004). The effect of corruption on Japanese foreign direct investment. Journal of Business Ethics, 50(3), 211-224. https://doi.org/10.1023/B:BUSI.0000024737.57926.bf

Walsh, P. J., \& Yu, J. (2010). Determinants of foreign direct investment: A sectoral and institutional Approach. IMF Working Paper WP/10/187, Washington D.C.: International Monetary Fund, 24. https://doi.org/10.5089/9781455202218.001

Zhang, S., \& Chen, C. L. (2020). Does outward foreign direct investment facilitate China's export upgrading? China \& World Economy, 28(5), 64-89. https://doi.org/10.1111/cwe.12328

Zongzheng, L., \& Mao, J. (2019). How do tax incentives affect investment and productivity? Firm-level evidence from China. American Economic Journal: Economic Policy, 11(3), 261-291. https://doi.org/10.1257/pol.20170478 